University of Nebraska - Lincoln

DigitalCommons@University of Nebraska - Lincoln

Faculty Papers and Publications in Animal

Science

Animal Science Department

1970

\title{
Diammonium Citrate and Diammonium Phosphate as Sources of Dietary Nitrogen for Growing-Finishing Swine
}

\author{
G. F. Wehrbein \\ University of Nebraska-Lincoln \\ P. E. Vipperman Jr. \\ University of Nebraska-Lincoln \\ E. R. Peo, Jr. \\ University of Nebraska-Lincoln \\ P. J. Cunningham \\ University of Nebraska-Lincoln
}

Follow this and additional works at: https://digitalcommons.unl.edu/animalscifacpub

Part of the Animal Sciences Commons

Wehrbein, G. F.; Vipperman, P. E. Jr.; Peo, Jr., E. R.; and Cunningham, P. J., "Diammonium Citrate and Diammonium Phosphate as Sources of Dietary Nitrogen for Growing-Finishing Swine" (1970). Faculty Papers and Publications in Animal Science. 632.

https://digitalcommons.unl.edu/animalscifacpub/632

This Article is brought to you for free and open access by the Animal Science Department at DigitalCommons@University of Nebraska - Lincoln. It has been accepted for inclusion in Faculty Papers and Publications in Animal Science by an authorized administrator of DigitalCommons@University of Nebraska - Lincoln. 


\title{
DIAMMONIUM CITRATE AND DIAMMONIUM PHOSPHATE AS SOURCES OF DIETARY NITROGEN FOR GROWING-FINISHING SWINE ${ }^{1}$
}

\author{
G. F. Wehrbein, P. E. Vipperman, Jr., E. R. Peo, Jr. and P. J. Cunningham ${ }^{2}$ \\ Nebraska Agricultural Experiment Station, Lincoln
}

$\mathbf{M}^{\mathrm{A}}$ ANY scientists are concerned about the possibility of a protein shortage in the near future. Since the pig will be placed in direct competition with man for many of the proteins presently used in feeds, it has become increasingly important to determine if other sources of nitrogen can serve as a replacement for some of the non-essential amino acid nitrogen in natural proteins.

The exact relationship between "non-essential" and "essential" amino acid nitrogen of a given diet is not fully understood. It is assumed that if the diet does not supply an adequate quantity of nitrogen for the "nonessential" amino acids, they must be synthesized from nitrogen supplied by the "essential" amino acids that are present. Thus, provisions in the diet for adequate quantities of non-protein nitrogen (NPN) for "nonessential" amino acid synthesis should allow the use of minimal quantities of the "essential" amino acids in diet formulation.

Most, if not all, of the research concerning NPN utilization by swine has involved urea. While Liu et al. (1955) showed that limited amounts of ${ }^{15} \mathrm{~N}$-labeled urea nitrogen were incorporated into the proteins of various body tissues, growth studies with swine fed urea have not been promising (Hanson and Ferrin, 1955; Hays et al., 1957; Kornegay et al., 1964, 1965).

Since urea is a natural excretory product, some other nitrogen source may be more effective in supplying a portion of the nitrogen requirement of swine. Two experiments were therefore conducted in which a portion of the dietary nitrogen supplied by soybean meal in diets for growing swine was replaced by an equimolar mixture of diammonium citrate (DAC) and diammonium phosphate (DAP).

\section{Methods and Materials}

In Experiment 1, 60 Yorkshire x Hampshire pigs averaging $27.3 \mathrm{~kg}$ were randomly as-

1 Published with the approval of the Director as Paper No. 1 Published with the approval of the Direct
2654, Journal Series, Nebr. Agr. Exp. Sta.

2 Department of Animal Science. Acknowledgement is made to Pleasant J. Cunningham for assistance in caring for the experimental animals and to Dawes Laboratories, Inc., Chirago, for providing the vitamin premix used in the experimental diets. signed by weight within sex and littermate groups to five replicated dietary treatments. Each replication consisted of three gilts and three barrows. Treatments were randomly assigned to each replication. The study lasted 81 days and was conducted during the winter months.

All pigs were housed in wooden sheds open to concrete pens. The pens were cleaned daily and the sheds were bedded with straw. The pigs were fed from self feeders and given free access to water. Supplemental light was provided by overhead yard lights during the night hours.

The composition of the experimental diets is shown in table 1. All diets contained approximately $16 \%$ crude protein $(\mathrm{N} \times 6.25)$ until the pigs weighed approximately 50.5 kilograms. At this time, all diets were adjusted to $14 \%$ crude protein and fed for the remainder of the experimental period. Diet A was a standard corn-soybean meal diet used as a positive control. In diets $B, C$ and $D$, respectively, 5, 10 and $20 \%$ of the dietary nitrogen was replaced by an equimolar mixture of DAC and DAP. Cornstarch was added to make the diets isocaloric. Dict $\mathrm{E}$ was the same as Diet D except DL-methionine, Llysine and DL-trytophan were added to approximate the level of these amino acids found in Diet A.

The pigs were weighed and feed intake was determined at 2-week intervals throughout the experimental period. Approximately $6 \mathrm{ml}$ of blood was withdrawn with heparinized Becton-Dickinson vacutainers from the brachial viens of two gilts and two barrows selected at random from each treatment within each replication on day 58 of the experimental period. The samples were frozen and analyzed at a later date. Blood nitrogen (BN) was determined by the micro-Kjeldahl method as outlined in A.O.A.C. (1960) and blood urea nitrogen (BUN) was determined by the method described by Conway (1957).

All pigs were probed for backfat at approximately $95.5 \mathrm{~kg}$ body weight. The barrows were slaughtered and carcass length and ham and loin weights were obtained. Since 
WEHRBEIN ET AL.

TABLE 1. COMPOSITION OF EXPERIMENTAL DIETS

\begin{tabular}{|c|c|c|c|c|c|c|c|c|}
\hline \multirow[b]{2}{*}{ Treatments } & \multicolumn{5}{|c|}{ Experiment 1} & \multicolumn{3}{|c|}{ Experiment 2} \\
\hline & A & B & $\mathrm{C}$ & $\mathrm{D}$ & $\mathrm{E}$ & $\mathbf{F}$ & G & $\mathbf{H}$ \\
\hline $\begin{array}{l}\text { NPN, \% } \\
\text { Crude protein (N x 6.25), \% } \\
\text { Calcium, \% } \\
\text { Phosphorus, \% }\end{array}$ & $\begin{array}{r}0 \\
16.00 \\
0.65 \\
0.65\end{array}$ & \begin{aligned} \multicolumn{1}{c}{5} \\
16.00 \\
0.65 \\
0.65\end{aligned} & $\begin{array}{r}10 \\
16.00 \\
0.65 \\
0.65\end{array}$ & $\begin{array}{r}20 \\
16.00 \\
0.65 \\
0.65\end{array}$ & $\begin{array}{c}20+\mathbf{A A}^{\mathbf{a}} \\
16,30 \\
0.65 \\
0.65\end{array}$ & $\begin{array}{r}0 \\
12.80 \\
0.65 \\
0.65\end{array}$ & $\begin{array}{r}20 \\
16.00 \\
0.65 \\
0.65\end{array}$ & $\begin{array}{c}20+\mathrm{AA}^{\mathrm{a}} \\
16.30 \\
0.65 \\
0.65\end{array}$ \\
\hline Ingredients & & & & & & & & \\
\hline $\begin{array}{l}\text { Ground yellow corn } \\
\text { Soybean meal ( } 50 \% \text { ) } \\
\text { Diammonium phosphate } \\
\text { Diammonium citrate }\end{array}$ & $\begin{array}{c}77.74 \\
18.40 \\
\cdots \\
\cdots\end{array}$ & $\begin{array}{r}77.74 \\
16.80 \\
0.39 \\
0.52\end{array}$ & $\begin{array}{r}77.74 \\
15.20 \\
0.77 \\
1.04\end{array}$ & $\begin{array}{r}77.74 \\
12.00 \\
1.54 \\
2.07\end{array}$ & $\begin{array}{r}77.74 \\
12.00 \\
1.54 \\
2.07\end{array}$ & $\begin{array}{r}77.74 \\
12.00 \\
\ldots \\
\ldots\end{array}$ & $\begin{array}{r}77.74 \\
12.00 \\
1.54 \\
2.07\end{array}$ & $\begin{array}{r}77.74 \\
12.00 \\
1.54 \\
2.07\end{array}$ \\
\hline $\begin{array}{l}\text { Dicalcium phosphate } \\
\quad \text { (18.5\% P) } \\
\text { Ground limestone } \\
\text { Trace mineral }{ }^{\mathrm{b}} \\
\text { Salt (1) } \\
\text { Vitamin antibiotic premix } \\
\text { DL-methionine (100\%) } \\
\text { L-lysine (20\%) } \\
\text { DL-tryptophan (100\%) } \\
\text { Cornstarch }\end{array}$ & $\begin{array}{l}1.82 \\
0.44 \\
0.10 \\
0.50 \\
1.00 \\
\cdots \\
\cdots \\
\cdots\end{array}$ & $\begin{array}{l}1.45 \\
0.68 \\
0.10 \\
0.50 \\
1.00 \\
\ldots \\
\ldots \\
\ldots .82\end{array}$ & $\begin{array}{l}1.05 \\
0.95 \\
0.10 \\
0.50 \\
1.00 \\
\ldots \ldots \\
\ldots \ldots \\
1.65\end{array}$ & $\begin{array}{l}0.30 \\
1.44 \\
0.10 \\
0.50 \\
1.00 \\
\cdots \\
\cdots \\
\cdots \cdots \\
3.31\end{array}$ & $\begin{array}{l}0.30 \\
1.44 \\
0.10 \\
0.50 \\
1.00 \\
0.05 \\
0.99 \\
0.05 \\
2.22\end{array}$ & $\begin{array}{l}2.04 \\
0.34 \\
0.10 \\
0.50 \\
1.00 \\
\ldots \\
\ldots \\
\ldots .28\end{array}$ & $\begin{array}{l}0.30 \\
1.44 \\
0.10 \\
0.50 \\
1.00 \\
\ldots \ldots \\
\ldots \ldots \\
3.31\end{array}$ & $\begin{array}{l}0.30 \\
1.44 \\
0.10 \\
0.50 \\
1.00 \\
0.05 \\
0.99 \\
0.05 \\
2.22\end{array}$ \\
\hline
\end{tabular}

a $0.05 \%$ methionine; $0.02 \%$ lysine; $0.05 \%$ tryptophan.

b Composition $(\%): \mathrm{Mn}, 10.0 ; \mathrm{Fe} ; 10.0 ; \mathrm{Cu}, 1.0 ; \mathrm{Co}, 0.10 ; 1,0.30 ; \mathrm{Zn}, 10.0$. Calcium Carbonate Company, Qunicy, I1l. c Composition per $\mathrm{kg}$ diet: vit. A, 3168 IU; vt. $\mathrm{D}_{2}, 475$ IU; riboflavin, $2.11 \mathrm{mg}$; pantothenic acid, $7.90 \mathrm{mg}$; niacin, $21.1 \mathrm{mg}$ : choline chloride, $132 \mathrm{mg}$; vit. B12, $13 \mu \mathrm{g} ;$ chlortetracycline, $44 \mathrm{mg}$.

the DAP also served as a source of phosphorus, the left hind foot of each pig was collected at the time of slaughter to determine bone length (BL), width (BW), thickness (BT), and breaking strength (BKS) of the fourth metatarsal. The length of the diaphysis of the fourth metatarsal was measured to determine BL. The smaller diameter of the wide and narrow side of the diaphysis, respectively, was measured to determnie $B W$ and BT. The BKS of the bone was determined according to the method described by Libal et al. (1969). Percent ash of the moisturefree, fat-free fourth metatarsal bone was determined according to the methods outlined in A.O.A.C. (1960).

Experiment 2 was conducted to determine the comparative nitrogen retention and blood characteristics of pigs fed NPN. Two Yorkshire $\mathrm{x}$ Hampshire barrows selected from each of three litters were utilized. Based upon average daily feed consumption within each pair of littermates, the pigs were divided into two groups (high and low daily feed intake). The amount of feed given each pig was based upon the lowest individual feed consumption within each group adjusted to metabolic body size $\left(\mathrm{W}^{0.75}{ }_{\mathrm{kg}}\right.$ Kleiber, 1947). The experiment was divided into three periods. Each period consisted of 8 days, 3 days for the pigs to adjust to their respective diets and 5 days for the collection period. Three experimental diets were randomly assigned and rotated within each group in a $3 \times 3$ latin square design.

The composition of the diets is shown in table 1. Diet F (low protein) was considered a negative control containing $12.8 \%$ crude protein $(\mathrm{N} \times 6.25)$ from corn and soybean meal. Diets $G$ and $H$ were identical to Diets $\mathrm{D}$ and $\mathrm{E}$ of Experiment 1.

The pigs were kept in adjustable circular metabolism crates and the temperature of the experimental unit was maintained at approximateliy 24 centigrade. Collection procedures were similar to those described by Luce et al. (1966).

Nitrogen determination of the feed, feces and urine was in accordance with the Kjeldahl method as outlined in A.O.A.C. (1960). Calcium level of the urine was determined colorimetrically with a Beckman spectrophotometer by the Ferro-Ham Method (1957). Calcium level of the feed and feces was determined by titration following the method described by Hunt (1963). Phosphorus levels were determined colorimetrically as outlined by Sumner (1944).

Approximately $6 \mathrm{ml}$ of blood was withdrawn from each pig on the last day of each experimental period. The method of collecting the blood and the analyses for blood urea nitrogen and percent nitrogen were as outlined in Experiment 1.

The data were analyzed statistically by 
analysis of variance methods as outlined by Steel and Torrie (1960).

\section{Results}

A summary of the gain and feed conversion data for Experiment 1 is shown in table 2 . Average daily gain decreased as increments of NPN were doubled. The addition of $0.20 \%$ L-lysine, $0.05 \%$ DL-methionine and $0.05 \%$ DL-tryptophan to the $20 \%$ NPN did increase average daily gain and feed intake in amounts that approached significance when compared to the 20\% NPN diet without amino acids. Gains for the pigs fed Diets A, B and C were not significantly different; however, they were significantly $(\mathrm{P}<.005)$ greater than for the pigs fed Diets $D$ and E. As might be expected, barrows gained significantly faster $(\mathrm{P}<.025)$ than gilts.

Gain per unit of feed was greater $(\mathrm{P}<.005)$ for the pigs fed Diets A, B and C compared to Diets $D$ and $E$. There was no effect of added amino acids (Diet E) upon gain per unit of feed compared to Diet D (20\% NPN diet).

A summary of the blood, bone and carcass data for Experiment 1 is also shown in table 2. While the percent total nitrogen in blood was unaffected by dietary treatment, there was a significant $(\mathrm{P}<.05)$ treatment effect on BUN levels. BUN levels decreased as the increments of NPN were doubled in the diet. The values for the pigs fed Diets A, B and $\mathrm{C}$ were significantly $(\mathrm{P}<.01)$ higher than for pigs fed Diets $\mathrm{D}$ and $\mathrm{E}$. The addition of the amino acids to the $20 \%$ NPN diet resulted in a further decrease in BUN. Barrows had significantly $(\mathrm{P}<.025)$ higher $\mathrm{BUN}$ levels than the gilts.

A trend toward higher $\mathrm{BKS}$ for the pigs fed DAC and DAP was noted. BKS values were greater $(\mathrm{P}<.10)$ for the pigs fed Diets $\mathrm{B}$ and $\mathrm{E}$, respectively, compared to the pigs fed Diets A and D. Bone Length, width,

TABLE 2. GAIN, FEED CONVERSION, AND CERTAIN BLOOD AND BONE CHARACTERISTICS OF GROWING-FINISHING SWINE FED NPN ${ }^{a}$

\begin{tabular}{|c|c|c|c|c|c|}
\hline \multirow[b]{2}{*}{ Treatments } & \multicolumn{5}{|c|}{ Experiment 1} \\
\hline & A & $\mathbf{B}$ & $\mathrm{C}$ & $\mathrm{D}$ & $\mathrm{E}$ \\
\hline NPN, \% & 0 & 5 & 10 & 20 & $20+\mathbf{A A}^{b}$ \\
\hline \multicolumn{6}{|l|}{ Criterion } \\
\hline \multicolumn{6}{|l|}{ Avg daily gain, $\mathrm{kg}$} \\
\hline $1-35$ days & 0.78 & 0.76 & 0.73 & 0.65 & 0.73 \\
\hline $36-81$ days & 0.90 & 0.88 & 0.87 & 0.78 & 0.80 \\
\hline $1-81$ days & 0.85 & 0.83 & 0.81 & 0.72 & $0.77^{\mathrm{c}}$ \\
\hline Barrows & 0.88 & 0.86 & 0.83 & 0.76 & $0.81^{d}$ \\
\hline Gilts & 0.81 & 0.80 & 0.78 & 0.68 & $0.73^{\mathrm{d}}$ \\
\hline Avg daily feed intake, $\mathrm{kg}$ & 2.92 & 2.77 & 2.73 & 2.57 & $2.70^{\circ}$ \\
\hline Gain/feed & 0.29 & 0.30 & 0.30 & 0.28 & $0.28^{t}$ \\
\hline Blood urea nitrogen $(\mathrm{mg} / 100 \mathrm{ml})$ & 19.57 & 17.58 & 16.35 & 15.73 & $13.73^{\mathrm{g}}$ \\
\hline Barrows & 20.30 & 20.60 & 16.57 & 16.89 & $15.07^{d}$ \\
\hline Gilts & 18.84 & 14.55 & 16.13 & 14.58 & $12.40^{d}$ \\
\hline Blood nitrogen, $\%$ & 2.93 & 3.02 & 3.06 & 3.03 & 3.04 \\
\hline Bone length, $\mathrm{cm}$ & 5.68 & 5.66 & 5.66 & 5.79 & 5.76 \\
\hline Bone width, cm & 1.53 & 1.54 & 1.56 & 1.53 & 1.54 \\
\hline Bone thickness, $\mathrm{cm}$ & 1.24 & 1.26 & 1.29 & 1.25 & 1.29 \\
\hline Bone breaking strength, kg & 161.30 & 189.10 & 174.70 & 170.70 & $194.80^{\mathrm{h}}$ \\
\hline Bone ash, \% & 58.43 & 57.34 & 57.58 & 58.05 & 57.95 \\
\hline Backfat thickness, cm & 3.80 & 3.40 & 3.60 & 3.50 & $3.50^{i}$ \\
\hline Barrows & 4.10 & 3.50 & 3.60 & 3.70 & $3.60^{d}$ \\
\hline Gilts & 3.40 & 3.30 & 3.60 & 3.30 & $3.40^{\mathrm{d}}$ \\
\hline \multicolumn{6}{|l|}{ Carcass length, $\mathrm{cm}$} \\
\hline Barrows & 76.40 & 76.60 & 75.50 & 76.30 & 74.40 \\
\hline \multicolumn{6}{|l|}{ Ham and loin, $\%$} \\
\hline Barrows & 36.40 & 37.00 & 36.90 & 37.10 & 38.00 \\
\hline
\end{tabular}

a Two replicates, 6 pigs/pen; initial wt. $27.3 \mathrm{~kg}$; final wt. $95.5 \mathrm{kilograms.}$

b Supplemented with $0.05 \%$ methionine, $0.20 \%$ lysine; $0.05 \%$ tryptophan

c Treatment effect sig. $\mathrm{P}<.05$; Difference between A, B, C vs. D, E sig. $\mathrm{P}<.005$.

d Sex effect sig. $\mathrm{P}<.025$

- Treatment effect sig. P<.10; Difference between $\mathrm{A}, \mathrm{B}, \mathrm{C}$ vs. D, E sig. P<.025

f Treatment effect sig. $\mathrm{P}<.05$; Difference between A, B, C vs. D, E sig. $\mathrm{P}<.005 ;$ Difference between A vs. B sig. P<.10.

Treatment effect sig. $\mathrm{P}<.05$; Difference between $\mathrm{A}, \mathrm{B}, \mathrm{C}$ vs. $\mathrm{D}, \mathrm{E}$ sig. $\mathrm{P}<01$; Difference between $\mathrm{A}, \mathrm{B}$ vs. C; $\mathrm{A}$ vs. $\mathrm{B}$ $D$ vs. $\mathrm{E}$ sig. $\mathrm{P}<.10$.

$\mathrm{h}$ Difference between A vs. $\mathrm{B}$ sig. $\mathrm{P}<.10$; Difference between $\mathrm{D}$ ขs. $\mathrm{E}$ sig. $\mathrm{P}<.10$.

1 Difference between $\mathrm{A}$ vs. $\mathrm{B}$ sig. $\mathrm{P}<\mathrm{i} 0$. 
TABLE 3. NITROGEN, CALCIUM AND PHOSPHORUS RETENTION OF GROWING SWINE FED NPN

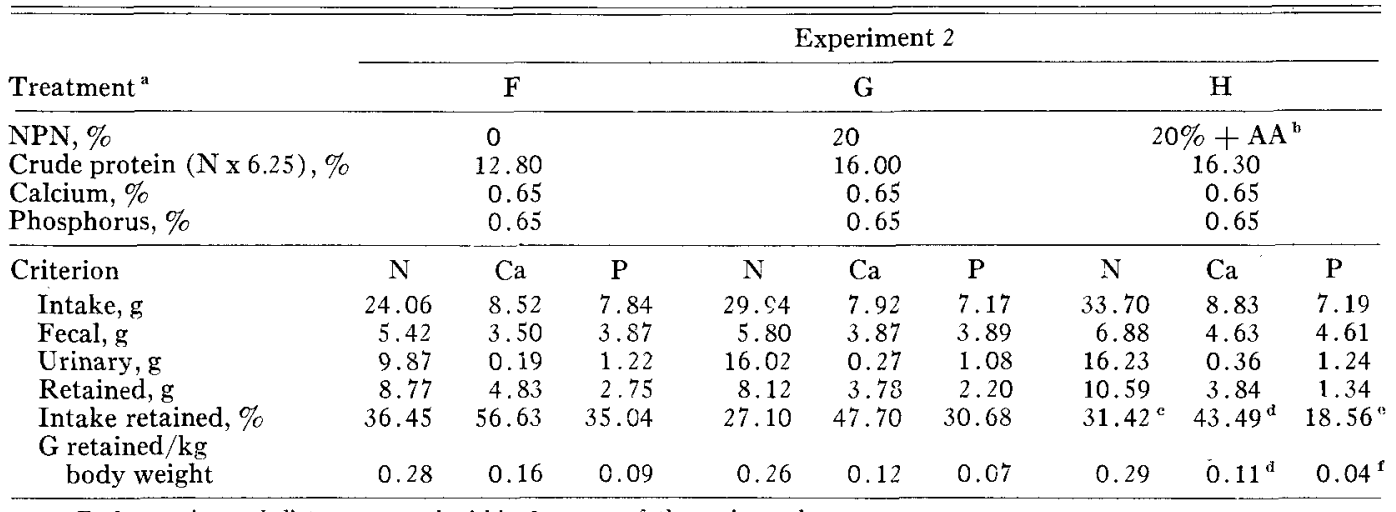

a Each experimental diet was rotated within 2 groups of three pigs each.

b Supplemented with $0.05 \%$ methionine; $0.20 \%$ lysine; $0.05 \%$ tryptophan

- Treatment effect sig. P<.05; Difference between F is. G, H sig. P<. 025 .

d Treatment effect sig. $\mathrm{P}<.05 ;$ Difference between $F$ vs. G, H sig. $\mathrm{P}<.025$

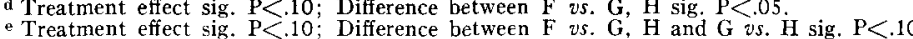

f Treatment effect sig. $\mathrm{P}<.05 ;$ Difference between $\mathrm{F}$ vs. $\mathrm{G}, \mathrm{H}$ sig. $\mathrm{P}<.05 ;$ Difference between $\mathrm{G}$ vs. $\mathrm{H}$ sig. $\mathrm{P}<.10$,

thickness, and percent ash were not affected by dietary treatment.

Carcass length and percent ham and loin were unaffected by the level of NPN in the diet. There was a trend toward reduced backfat in pigs fed NPN. Backfat thickness was greater $(\mathbf{P}<.025)$ for barrows than for gilts.

A summary of the nitrogen, phosphorus and calcium retention for Experiment 2 is shown in table 3. Pigs fed Diet F retained a greater $(\mathrm{P}<.025)$ percent of ingested nitrogen than pigs fed Diets $\mathrm{G}$ and $\mathrm{H}$; however, nitrogen retention (expressed as grams retained per $\mathrm{kg}$ body weight) was not affected by dietary treatment. Percent ingested phosphorus retained was $(\mathrm{P}<.10)$ greater for the pigs fed Diet $\mathrm{F}$ than for those receiving Diets $\mathrm{G}$ and $\mathrm{H}$. In addition, pigs fed Diet $\mathrm{G}$ retained more phosphorus $(P<.10)$ than the pigs fed Diet $H$. A decrease in percent calcium $(\mathrm{P}<.05)$ retained was observed for pigs

TABLE 4. CERTAIN BLOOD CHARACTERISTICS OF GROWING SWINE FED NPN

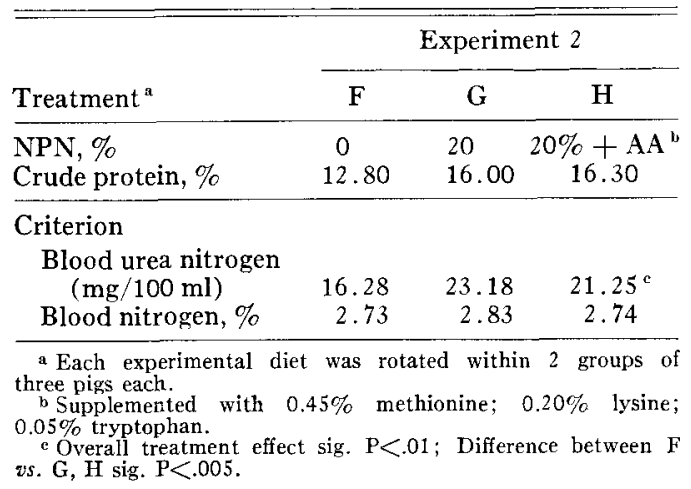

fed Diets $\mathrm{G}$ and $\mathrm{H}$ compared to those fed Diet F.

A summary of the blood data for Experiment 2 is shown in table 4 . BUN levels were significantly $(\mathrm{P}<.005)$ lower for the pigs fed Diet $F$ than for the pigs fed Diets $G$ and $H$. Percent nitrogen of the blood was unaffected by dietary treatment.

\section{Discussion}

The replacement of $0,5,10$ and $20 \%$ of the dietary nitrogen by an equimolar mixture of DAC and DAP in a diet for growing swine resulted in decreased average daily gain and feed intake. The greatest decrease was noted when $20 \%$ NPN was added. This depression was similar throughout the experimental period. Similar results have been reported by Hays et al. (1957) when urea was used as the source of NPN, but Kornegay et al. (1965) found that 2.5\% urea included to replace an equivalent amount of soybean meal nitrogen in a $17 \%$ crude protein corn-soybean meal diet did not significantly affect average daily gain and feed intake. The gain depression noted with the $20 \%$ NPN diet was not as great when $0.20 \%$ L-lysine, $0.05 \%$ DL-methionine and $0.05 \%$ DL-tryptophan were added.

Blood urea nitrogen decreased as the increments of NPN were doubled in the diets. A further decrease was noted when amino acids were added to the $20 \%$ NPN diet (table 2). This is in direct conflict with the results found in Experiment 2 (table 4). Hays et al. (1957) reported that serum blood urea nitrogen values were higher for pigs fed urea. 
However, Kornegay et al. (1965) reported that serum blood urea was higher for pigs fed urea during the initial part of the growing-finishing period, but urea nitrogen values for these pigs were not different from those pigs fed no urea toward the end of the finishing period. Percent nitrogen of whole blood was unaffected by dietary treatment.

The tendency for pigs fed the control diet to have thicker backfat and a lower percent of ham and loin than the pigs fed NPN may be due to the reduced feed intake for the pigs fed NPN. Crampton, Ashton and Lloyd (1954) reported that restriction of feed intake during the finishing period reduced backfat thickness and increased percent ham and loin.

Nitrogen retention, expressed as grams of nitrogen retained per $\mathrm{kg}$ body weight, tended to be higher for the pigs fed Diet F (low protein) and Diet $\mathrm{H}$ (low protein plus NPN and amino acids) compared with Diet G. Rose $e t a l$. (1949) demonstrated that rats can utilize some of the nitrogen furnished by NPN if adequate amounts of the essential amino acids are present. The addition of NPN to
Diet $\mathrm{F}$ (low protein) resulted in a $62 \%$ increase in urinary nitrogen.

Figure 1 shows nitrogen, phosphorus, and calcium retention expressed in grams retained per $\mathrm{kg}$ body weight. Calcium and phosphorus retention followed the same pattern noted for the nitrogen except when lysine, methionine, and tryptophan were added to the low protein plus NPN diet. The addition of the amino acids (Diet $\mathrm{H}$ ) resulted in an apparent increase in nitrogen retained but less calcium and phosphorus were retained when compared with Diet G. The latter observation is unexplained at this time but was a consistent finding for every animal exposed to these dietary treatments.

BUN levels were significantly lower in pigs fed Diet $F$ (low protein) compared with pigs fed Diet G (low protein plus NPN). This conflicts with the results reported in Experiment 1 , but in Experiment 2 the total nitrogen level was greater in the NPN supplemented diets; whereas, in Experiment 1 all diets were isonitrogenous. Also the pigs were heavier when blood samples were collected in Experiment 1 and had a longer time to
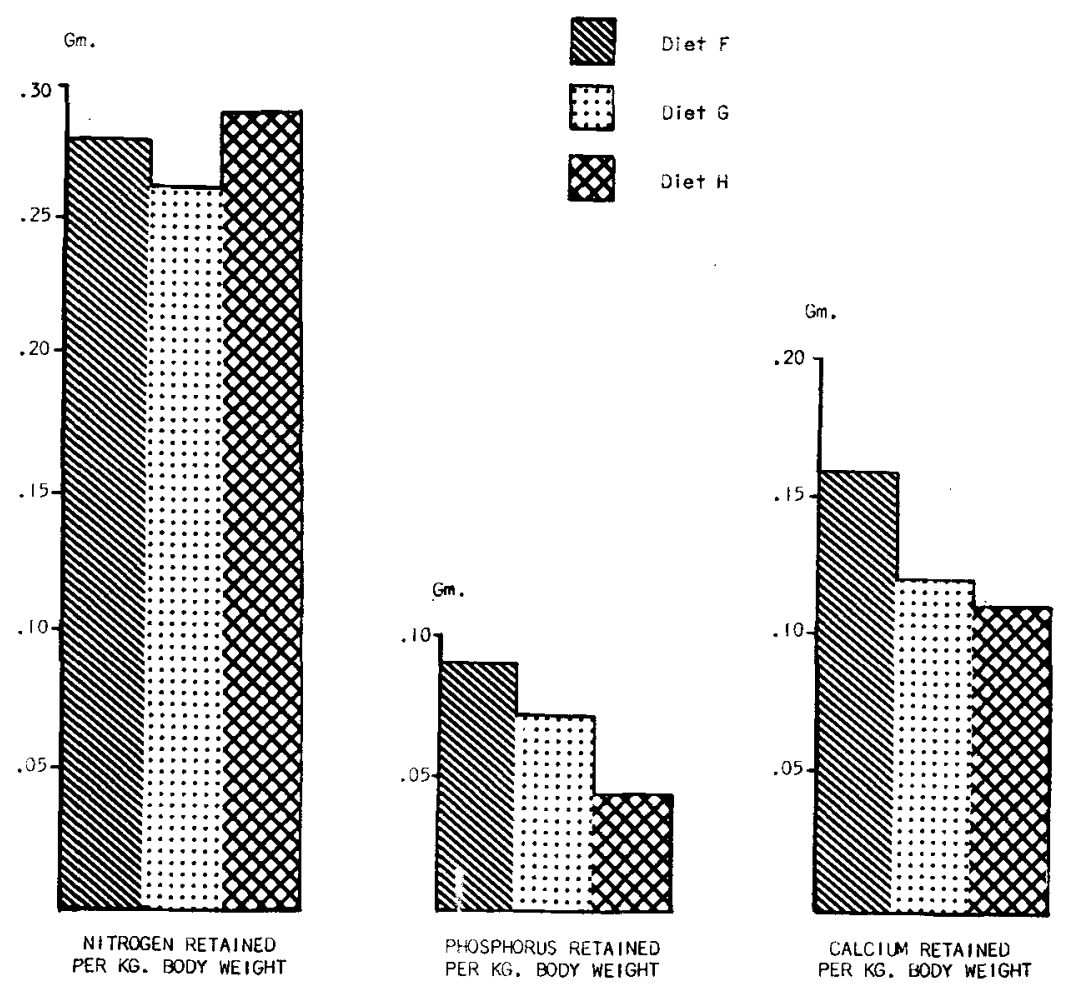

Figure 1. Nitrogen, Phosphorus, and Calcium Retention for Growing Swine fed NPN. (Low Protein, Diet F; Low Protein plus NPN, Diet G; Low Protein plus NPN and Amino Acids, Diet $H$ ). 
adjust to the NPN diets. As in Experiment 1, total nitrogen of whole blood was not significantly affected by dietary treatment.

\section{Summary}

Two experiments were conducted with 66 pigs to determine the effect of replacing 0,5 , 10 or $20 \%$ of the protein in a diet for growing swine with non-protein nitrogen (NPN) from an equimolar mixture of diammonium citrate and diammonium phosphate. Criteria of response were rate of gain, gain/feed, nitrogen retention and certain blood and carcass characteristics. Since the DAP was also considered as a source of phosphorus, its effects on certain bone characteristics and the retention of calcium and phosphorus were determined.

Average daily gain, feed intake and blood urea nitrogen values decreased as the increments of supplemented NPN were doubled in the diets. However, the decrease in average daily gain was significant only for the pigs fed the 20\% NPN diet compared to the control.

Results from the metabolism study showed that the addition of NPN to the diet reduced nitrogen retained per unit of body weight. This effect was reversed by the addition of $0.05 \%$ DL-methionine, $0.20 \%$ L-lysine and $0.05 \%$ DL-tryptophan to the diet. An unexplained decline in phosphorus retention was noted when the supplemental amino acids were employed.

\section{Literature Cited}

A.O.A.C. 1960. Official Methods of Analysis (9th Ed.). Association of Official Agricultural Chemists. Washington, D. C.
Conway, E. J. 1957. Microdiffusion Analysis and Volumetric Error (4th Ed.). Crosby Lockwood, London.

Crampton, E. W., G. C. Ashton and L. E. Lloyd. 1954. The effect of restricting feed intake of market hogs during the finishing period on the quality of the bacon carcass. J. Anim. Sci. 13:321.

Ferror, P. V. and A. B. Ham. 1957. A simple spectrophotometric method for the determination of calcium. Amer. J. Clin. Pathology. 28:208.

Hanson, L. E. and E. F. Ferrin. 1955. The value of urea in a low protein ration for weanling pigs. J. Anim. Sci. 14:43.

Hays, V. W., G. C. Ashton, C. H. Liu, V. C. Speer and D. V. Catron. 1957. Studies on the utilization of urea by growing swine. J. Anim. Sci. 16:44.

Hunt, J. R. 1963. Rapid determination of calcium in feedstuffs, J. Agr. and Food Chem. 11:346.

Kleiber, M. 1947. Body size and metabolic rate. Physiol. Revs. 27:511.

Kornegay, E. T., E. R. Miller, D. E. Ullrey and J. A. Hoefer. 1964. Effects of urease immunization of growing pigs upon performance and blood and intestinal ureolysis. J. Anim. Sci. 23:688.

Kornegay, E. T., E. R. Miller, D. E. Ullirey, B. H. Vincent and J. A. Hoefer. 1965. Influence of dietary urea on performance, antibody production and hematology of growing swine. J. Anim. Sci. 24:951.

Libal, G. W., E. R. Peo, Jr., R. P. Andrews and P. E. Vipperman, Jr. 1969. Levels of calcium and phosphorus for growing-finishing swine. J. Anim. Sci. 28:331.

Liu, C. H., V. W. Hays, H. J. Svec, D. V. Catron, G. C. Ashton and V. C. Speer. 1955. The fate of urea in growing pigs. J. Nutr. 57:241.

Luce, W. G., E. R. Peo, Jr. and D. B, Hudman. 1966. The availability of niacin in wheat for swine. J. Nutr. 88:39.

Rose, W. C., L. C. Smith, Madelyn Womack and M. Shane. 1949. The utilization of nitrogen of ammonium salts, urea, and certain other compounds in the synthesis of non-essential amino acids in vivo. J. Biol. Chem. 181:307.

Steel, R. G. D. and J. H. Torrie. 1960. Principles and Procedures of Statistics. McGraw-Hill Book Co., Inc., New York.

Sumner, J. B. 1944. A method for the calorimetric determination of phosphorus. Science 100:413. 